\title{
Appraisal of Groundwater Quality in Ado-Ekiti Metropolitan Area, Nigeria
}

\author{
Awopetu Michael Sanmi, Baruwa Abbas \\ Department of Civil Engineering, Faculty of Engineering, Ekiti State University, Ado - Ekiti, Nigeria
}

\begin{abstract}
This study examined the groundwater quality in Ado-Ekiti, Ekiti State, Nigeria. Water samples were randomly collected from ten hand-dug wells (HDW) covering the entire Ado-Ekiti metropolis. The water samples collected using standard method was promptly taken to water laboratory at the Federal Polytechnic AdoEkiti for analysis. Physical, chemical and bacteriological tests were carried out. Most physical, chemical and bacteriological parameters analysed were found to be at disparity with both Nigerian and World Health Organization (WHO) standard for drinking water quality. The ground water pollution may not be unconnected with poor and improper waste disposal. In order to guide against cholera and other water borne diseases, public enlightenment on proper waste management is require to be carried out. It is recommended that samples of well water use for drinking and other domestic chores should be taken to laboratory chemical and bacteriological tests once in six months.
\end{abstract}

Keywords-Quality, Groundwater, Bacteriological, AdoEkiti, Assessment, Waste Disposal.

\section{INTRODUCTION}

Groundwater is one of the world's most valuable natural drinking water resources. It is also utilized for agricultural purposes. Since it is filtered through the ground, it is often fresh and cold, and usually cleaner than surface water. Unfortunately, groundwater is threatened every day by people who do not even realize what it is or how they are affecting it. Groundwater is an essential part of the hydrological cycle and is a valuable natural resource providing the primary source of water for agriculture, domestic, and industrial uses in many Countries including Nigeria. The unique role of groundwater cannot be overemphasized. Groundwater has become a significant source of water for human consumption, supplying nearly half of all drinking water in the world [1] and around 43 percent of all water effectively consumed in irrigation [2].Groundwater is also important for sustaining streams, lakes, wetlands, and ecosystems in many countries. There is paucity of data though, it can be said that more than fifty percent of residents in Ado Ekiti metropolitan are largely depend on well (groundwater) as source of water for various uses.

The vulnerability of the ground water, especially of groundwater supplies, to existing or potential sources of contamination underscores the need for a systematic, detailed process by which these potential threats can be recorded and evaluated[3].It is easy for the importance of groundwater in water supplies to be underestimated. It is customary to think of groundwater as being more important in arid or semi-arid areasand surface water as more important in humid areas. However, inventories ofgroundwater and surface water use reveal the worldwide importance of groundwater[4].The reasons for this include its convenient availability close to where water is required,its excellent natural quality (which is generally adequate for potable supplies with little orno treatment) and the relatively low capital cost of development. Development in stages,to keep pace with rising demand, is usually more easily achieved for ground-water thanfor surface water.

Water is essential for life, but it can and does transmit disease across countries in all continents - from the poorest to the wealthiest, the disease carrying capacity of river does not recognize colour, boundary or race[5].There are no estimates of the public health consequences of groundwater pollution as it involvesmethodological complexities and logistical problems. Nevertheless, levels of toxicity depend onthe type of pollutant. Mercury is reported to cause impairment of brain functions, neurologicaldisorders, and retardation of growth in children, abortion and disruption of the endocrine system. The health implication of lead presence in excess of $0.01 \mathrm{mg} / \mathrm{l}$ in drinking water is cancer, interference with vitamin D metabolism, affect mental development in infants, toxic to the central and peripheral nervours systems [6].

Poorly constructed wells can result in ground water contamination. Construction problems, such as faulty casings or concrete rings, inadequate covers, or lack of concrete pads, allow outside water and any accompanying contaminants to flow into the well. Sources of such contaminants can be surface runoff or wastes from farm animals or septic systems. The thrust of this research is to 
examine the groundwater quality of Ado-Ekiti using laboratory water analysis sampled within the area. This became necessary as many inhabitants of the town depend mostly on groundwater to meet their daily water need.

\section{MATERIAL AND METHODS}

\subsection{THE STUDY AREA}

Ado Ekiti is a city in southwest Nigeria (Figure $1 \& 2$ ), the state capital and headquarters of the Ekiti. It is also known as Ado. It has a population of 308,621[7]. The projected population of Ado Ekiti in 2012 as put at 424, 340 by Wikipedia. The people of Ado Ekiti are mainly of the Ekiti sub-ethnic group of the Yoruba. Ado Ekiti (Figure 3) has three tertiary educational institutions namely: Ekiti State University, Afe Babalola University and The Federal Polytechnic Ado Ekiti. It also play host to two local television and radio stations; NTA Ado Ekiti, Ekiti State Television (BSES), Radio Ekiti and Progress FM Ado Ekiti. Various commercial enterprises operate in Ado Ekiti.

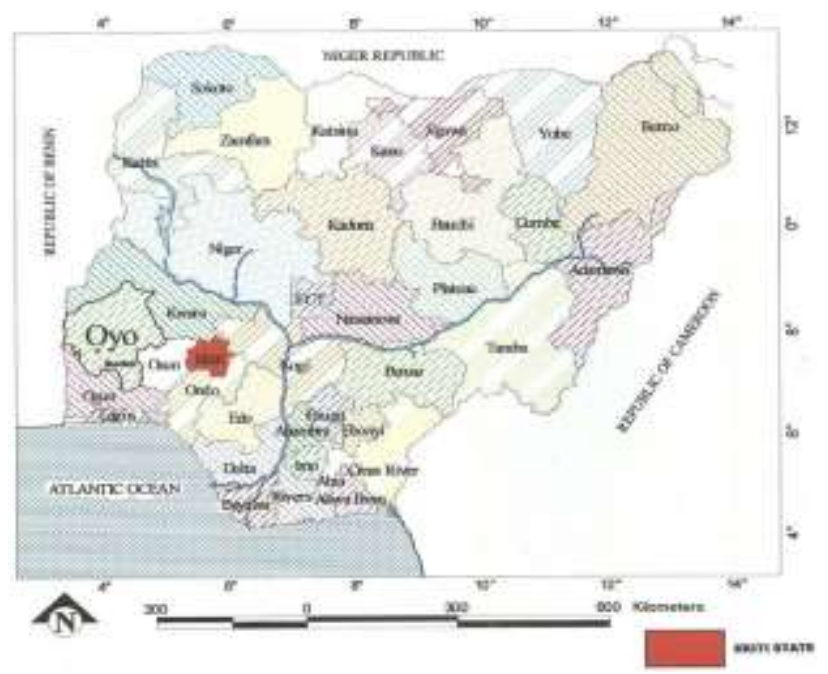

Fig.1: Map of Nigeria showing Ekiti State [8]
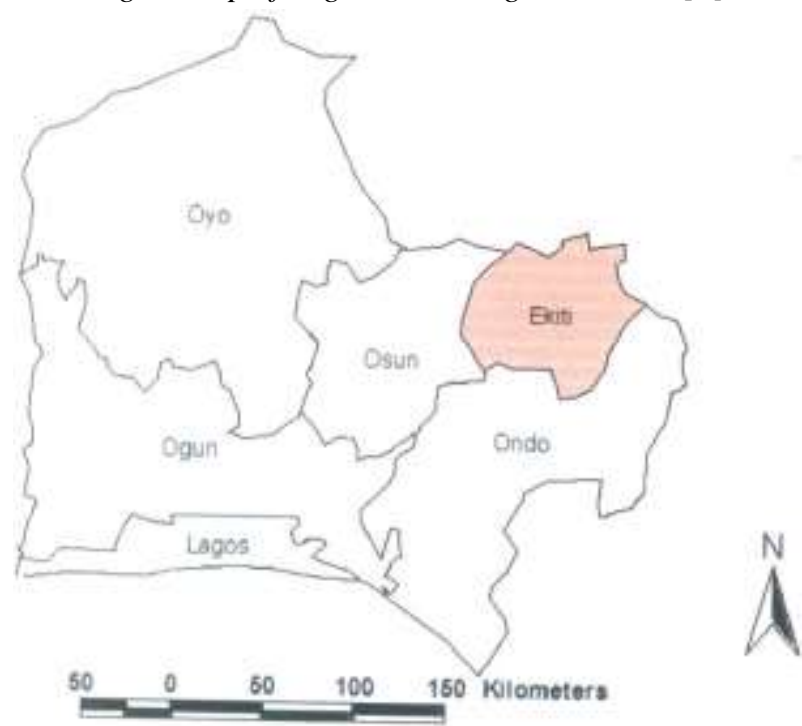

Fig.2: Map of South West Nigeria showing Ekiti State [8]
The town lies between the latitude $7^{0} 33^{1}$ and $7^{0} 42^{1}$ North of the equator and the longitude $5^{0} 11^{1}$ and $5^{0} 20^{1}$ East on a low-land surrounded by several isolated hills and inselbergs, [9].Geologically, the region lies entirely within the pre-Cambrian basement complex rock group, which underlies much of Ekiti State [10]. The temperature of this area is almost uniform throughout the year, with little deviation from the mean annual temperature of $27^{\circ} \mathrm{C}$. February and March are the hottest $28^{\circ}$ Cand $29^{\circ} \mathrm{C}$ respectively, while June with temperature of $25^{\circ} \mathrm{C}$ is the coolest[11]. The mean annual rainfall is $1,367 \mathrm{~mm}$ with a low co-efficient variation of about $10 \%$. Rainfall is highly seasonal with well-marked wet and dry season. The wet season lasts from April to October, with a break in August.

\subsection{SAMPLING DESIGN}

This study was carried out in the month of August during the rainy season. Water samples were collected from ten HDW all of which are within Ado metropolis. The ten wells where water samples were collected are assigned a representing symbol $\mathrm{N}$, thus,Nranges between $\mathrm{N} 1$ and N10. N1 was Oke Oniyo, N2 at Ajiosun, N3 at Olujoda, N4 at Okebola, N5 Ogbontitun, N6 at Housing Estate, N7 at Idemo, N8 at Oke-Ila, N9 at Ewegun and N10 at Olorunda area. The entire sampled well are within AdoEkiti metropolis with an average distance of about four kilometers.

\subsection{SAMPLE COLLECTION AND ANALYSIS PROCEDURE}

The water samples were collected during the morning hours under controlled temperature conditions using 2 liter properly labeled screw-capped sterile plastic container. Immediately after taking the sample, it was put in a potable cooler containing ice boxes in it so as to maintain the $4^{0} \mathrm{c}$ temperature before reaching the laboratory. The samples were then transported to Laboratory for water quality (The Federal Polytechnic Ado-Ekiti) analysis at least within 3 hours. The water samples were then analysed using quality control procedure for water quality analysis prescribed by the American Public Health Association [12].

\section{RESULTS AND DISCUSSION}

\subsection{Colour}

Nigerian standard for drinking water quality recommended maximum of 15 units while the world health organization (WHO) drinking water standard did not mention any guideline with respect to colour. However, the results showed below (Table 1) revealed that the entire sample analysed indicated 10 to 50 units which did not favoured the Nigerian standards mention above. The results of water sample collected at points $\mathrm{N} 2$, N8 and N9 only fell within the Nigerian standard. 
$3.2 \mathrm{pH}$

$\mathrm{pH}$ value or hydrogen ion concentration, gives an indication of the degree of acidity of the water. $\mathrm{pH} 7$ is neutral; values below 7 indicate acidic characteristics and values greater than 7 indicate alkaline characteristics. The minimum and maximum allowable $\mathrm{pH}$ range for portability is $6.5-8.5$, [13] and [15] recommended 6.58.8. The samples tested favoured both WHO and Nigerian standard for drinking water quality at points N2, N7 and N9.

\subsection{Turbidity}

The suspended matter causing turbidity is expected to be clay, silt, nonliving organic particles, plankton, and other microscopic organisms. It must be noted that turbidity can also be caused by precipitated calcium carbonate in hard waters, aluminum hydrate in treated water, and precipitated iron oxide in corrosive water. Since turbidity is removed by coagulation, sedimentation and filtration, none of these treatment measures was undertaking, thus, it may be unexpected the water samples may be of high turbidity. According to the WHO Turbidity of drinking water should be maintained under 5 units. The samples failed at point N1, N3, N6, N7, N8, N9 and N10 (Table 1a and 1a) to meet the WHO set standard.

Table.1a: Physical and chemical water sample analysis

\begin{tabular}{|c|c|c|c|c|c|}
\hline Parameters & N1 & $\mathbf{N 2}$ & N3 & N4 & N5 \\
\hline $\begin{array}{l}\text { Depth of Well } \\
\text { (m) }\end{array}$ & 10.4 & 8.25 & 5.60 & 6.0 & 7.5 \\
\hline Colour & 55.0 & 15.0 & 45 & 40 & 35 \\
\hline $\begin{array}{l}\text { Turbidity } \\
\text { (NTU) }\end{array}$ & 9.50 & 4.22 & 12.55 & 4.5 & 3.15 \\
\hline $\begin{array}{l}\text { Total Solids } \\
\text { (mg/l }\end{array}$ & 28.6 & 14.5 & 22.50 & 15.0 & 9.50 \\
\hline Suspended solid & 15.0 & 6.05 & 16.11 & 9.20 & 4.85 \\
\hline Dissolved Solid & 13.6 & 8.40 & 8.45 & 5.80 & 4.6 \\
\hline $\begin{array}{l}\text { Turbidity } \\
\text { (NTU) }\end{array}$ & 9.50 & 4.22 & 12.55 & 4.5 & 3.15 \\
\hline $\mathrm{pH}$ & 6.0 & 6.50 & 6.00 & 6.0 & 5.5 \\
\hline $\mathrm{DO}^{2}$ & 0.45 & 0.45 & 0.44 & 0.46 & 0.43 \\
\hline $\mathrm{Ca}^{+2}(\mathrm{mg} / \mathrm{l})$ & 102 & 20.2 & 13.9 & 16.5 & 22.5 \\
\hline $\mathrm{Mg}^{+2}(\mathrm{mg} / \mathrm{l})$ & 4.65 & 0.00 & 1.80 & 12.0 & 9.50 \\
\hline $\mathrm{CO}^{3}(\mathrm{mg} / \mathrm{l})$ & 0.0 & 0.00 & 0.00 & 0.00 & 0.0 \\
\hline $\mathrm{HCO}_{3}(\mathrm{mg} / \mathrm{l})$ & 60 & 12.50 & 16.50 & 46.7 & 23.5 \\
\hline Chloride (mg/l) & 21.0 & 11.05 & 93.5 & 13.75 & 16.50 \\
\hline Iron $(\mathrm{mg} / \mathrm{l})$ & 1.0 & 0.1 & 1.0 & 0.1 & 1.0 \\
\hline $\begin{array}{l}\text { Total hardness } \\
(\mathrm{mg} / \mathrm{l})\end{array}$ & 140 & 100 & 60 & 60 & 180 \\
\hline $\mathrm{NO}_{3}(\mathrm{mg} / \mathrm{l})$ & 0.01 & 0.02 & 0.01 & 0.01 & 0.02 \\
\hline $\mathrm{PO}_{3}(\mathrm{mg} / \mathrm{l})$ & 0.20 & 6.25 & 0.05 & 6.00 & 0.03 \\
\hline $\mathrm{HNO}_{3}(\mathrm{mg} / \mathrm{l})$ & 0.0 & 0.0 & 1.0 & 0.1 & 0.1 \\
\hline Lead (mg/l) & 0.0 & 0.0 & 0.0 & 0.0 & 0.0 \\
\hline
\end{tabular}

Table.1b:. Physical and chemical water sample analysis

\begin{tabular}{|l|l|l|l|l|l|}
\hline Parameters & N6 & N7 & N8 & N9 & N10 \\
\hline $\begin{array}{l}\text { Depth of Well } \\
(\mathrm{m})\end{array}$ & 11.2 & 7.0 & 7.2 & 9.0 & 6.8 \\
\hline Colour & 60 & 20 & 15 & 10 & 25 \\
\hline Turbidity (NTU) & 27.5 & 16.2 & 12.60 & 7.20 & 21.5 \\
\hline $\begin{array}{l}\text { Total Solids } \\
(\mathrm{mg} / \mathrm{l}\end{array}$ & 80.6 & 40.5 & 62.4 & 25.6 & 18.5 \\
\hline Suspended solid & 20.1 & 12.6 & 34.2 & 12.5 & 7.25 \\
\hline Dissolved Solid & 60.5 & 27.9 & 28.20 & 13.1 & 11.25 \\
\hline Turbidity (NTU) & 27.5 & 16.2 & 12.60 & 7.20 & 21.5 \\
\hline $\mathrm{pH}^{\mathrm{DO}}{ }^{2}$ & 5.5 & 6.5 & 6.0 & 6.8 & 6.2 \\
\hline $\mathrm{Ca}^{+2}(\mathrm{mg} / \mathrm{l})$ & 0.45 & 0.35 & 0.42 & 3.40 & 2.11 \\
\hline $\mathrm{Mg}^{+2}(\mathrm{mg} / \mathrm{l})$ & 23.5 & 14 & 20.0 & 40.5 & 30.1 \\
\hline $\mathrm{CO}^{3}(\mathrm{mg} / \mathrm{l})$ & 1.2 & 0.0 & 0.0 & 0.0 & 0.0 \\
\hline $\mathrm{HCO}_{3}(\mathrm{mg} / \mathrm{l})$ & 52.5 & 44.0 & 25.5 & 42.0 & 22.5 \\
\hline $\mathrm{Chloride}(\mathrm{mg} / \mathrm{l})$ & 100.7 & 64.2 & 72.4 & 40.8 & 24.8 \\
\hline $\mathrm{Iron}(\mathrm{mg} / \mathrm{l})$ & 1.5 & 1.5 & 1.2 & 1.0 & 0.1 \\
\hline $\begin{array}{l}\text { Total hardness } \\
(\mathrm{mg} / \mathrm{l})\end{array}$ & 20 & 120 & 80 & 100 & 100 \\
\hline $\mathrm{NO}_{3}(\mathrm{mg} / \mathrm{l})$ & 1.05 & 0.02 & 1.05 & 0.02 & 0.02 \\
\hline $\mathrm{PO}_{3}(\mathrm{mg} / \mathrm{l})$ & 0.03 & 0.02 & 0.03 & 0.01 & 0.01 \\
\hline $\mathrm{HNO}_{3}(\mathrm{mg} / \mathrm{l})$ & 2.0 & 0.0 & 0.01 & 0.01 & 1.0 \\
\hline $\mathrm{Lead}(\mathrm{mg} / \mathrm{l})$ & 0.1 & 0.0 & 0.0 & 0.0 & 0.05 \\
\hline
\end{tabular}

\subsection{Hardness}

Hardness may be considered a physical or chemical parameter of water. It represents the total concentration of calcium and magnesium ions, reported as calcium carbonate. In other words, "hard" water requires more soap to produce foam or lather. A voluminous body of literature suggests that in the United States and other developed nations, the incidence of many chronic disease but particularly cardiovascular disease (heart disease hypertension and stroke) is associated with various water characteristics related to hardness. However, the result in the table 1 below shows that the water is moderately hard and this can said to be okay as it complied with the Nigerian standard for drinking water quality.

\subsection{Calcium $\left(\mathrm{Ca}^{+2}\right)$}

The WHO has used $75 \mathrm{mg} / 1$ as a maximum acceptable limit for the international standards, and $200 \mathrm{mg} / 1$ as an excessive limit. However, the result of water sample in this study competes favourably with the [13] standards except at point N1 which is $102 \mathrm{mg} / \mathrm{l}$.

\subsection{Chloride}

Chloride is a component of common salt. It may occur in water naturally but it may be present due to local use of de-icing salt and saline intrusion. Both [15] and [13] standards for drinking water were silenced about Chloride. The European and National Drinking Water 
Quality Standards [14]documented chloride of an average $250 \mathrm{mg} / \mathrm{l}$ as drinking water standard recommended for quality of water intended for human consumption. All the water samples analysed compete favourably with the above standard.

\subsection{Lead (Pb)}

Nigerian standard for drinking water quality recommended $0.01 \mathrm{mg} / \mathrm{l}$ as maximum permitted lead in drinking water while WHO recommended zero (0) $\mathrm{mg} / \mathrm{l}$ in drinking water. The health implication of lead presence in excess of 0.01 in drinking water is cancer, interference with vitamin D metabolism, affect mental development in infants, toxic to the central and peripheral nervours systems. Lead were detected in only two (N6 and N10) out of ten water sample collected.

\subsection{Magnesium $\left(\mathrm{Mg}^{+2}\right)$}

Nigerian standard for drinking water quality recommended $0.2 \mathrm{mg} / \mathrm{l}$ as maximum permitted magnesium in drinking water. However, WHO drink water standard was silenced about magnesium in drinking water.

\subsection{Bacteriological quality}

The results of bacteriological test carried out in this study showed that the bacteriological quality of the water samples collected at various well points is nothing to write home about. The result shows most probable number (MPN) E-coli as high as 20/100 at sample collection point $\mathrm{N} 7$ (Table $2 \mathrm{a}$ and $2 \mathrm{~b}$ ) as against $0 / 100 \mathrm{ml}$ [13] standard. The health implications of E-coli presence in drinking water are: urinary track infections, bacteraemia, meningitis, diarrhea, (one of the main cause of morbidity and mortality among children), acute renal failure and haemolytic anaemia.

Table.2a:Bacteriological water sample Analysis Result

\begin{tabular}{|l|l|l|l|l|l|}
\hline Sample & N1 & N2 & N3 & N4 & N5 \\
\hline E-coli & 12 & 4 & 7 & 2 & 3 \\
\hline $\begin{array}{l}\text { Coliform count per 100ml } \\
\text { of sample }\end{array}$ & 45 & 12 & 17 & 13 & 13 \\
\hline
\end{tabular}

Table.2a: Bacteriological water sample Analysis Result

\begin{tabular}{|ll|l|l|l|l|l|}
\hline Sample & & N6 & N7 & N8 & N9 & N10 \\
\hline E-coli & & 15 & 20 & 16 & 4 & 14 \\
\hline $\begin{array}{l}\text { Coliform count } \\
\text { 100ml of sample }\end{array}$ & 46 & 12 & 40 & 8 & 5 \\
\hline
\end{tabular}

The results of water sample tests carried out in this study showed that, all the well water are either physically, chemically or bacteriologically contaminated. Thus the water is physically, chemically and bacteriological far from WHO as well as [15]. The main problem identified and established in this study is that well water quality within Ado Ekiti has deteriorated. The sources of groundwater contamination are many and varied, because, in addition to natural processes, practically every type of facility or structure installed by man and each and every human physical activity may eventually cause groundwater quality problems. However, source or sources of the said pollution which can be linked to indiscriminate disposal of solid wastes, improper construction of soak-away and septic tanks, as well as usage of herbicides for weed control. These sources of pollution should be investigated so that adequate measure can be taken mitigate the contaminants.

\section{CONCLUSION AND RECOMMENDATION}

In Ado-Ekiti, HDW represent a very significant proportion of the improved water supplies to the majority of the inhabitants. Such supplies which are once very common in the rural areas now represent a very significant proportion of the water supplies available and used by urban populations. Considering the population involved in the usage of this supply, the public health consequences of utilization of contaminated water from point source can be brutal with respect to epidemic, endemic, and pandemic diseases.

The HDW owners may not be aware of the fact that their well is contaminated. There should be a public enlightenment program by Government and NonGovernmental Organizations (NGO). Government, most especially at third tier should be able to keep record of all the HDW so as to facilitate free testing and treatment. A HDW policy may be formulated such that approval may be sought from ministry of water resources and environmental before an individual can dig a well. This will enhance proper location, construction to aquifer depth, testing and treatment of the HDW. Also as part of measure to ensure potability of HDW, water quality laboratory should be sited closed to the masses and the cost of water quality analysis be made quite affordable.

\section{REFERENCES}

[1] United Nations World Water Development Report 3 (WWAP). (2009) Water in a Changing World,World Water Assessment Programme. Paris, UNESCO Publishing, UNESCO.

[2] Siebert, S., Burke, J., Faures, J.M., Frenken, K., Hoogeveen, J., Döll, P. \& Portmann, F.T. (2010) Groundwater use for irrigation - a global inventory. Hydrology and Earth System Sciences.

[3] European and National Drinking Water Quality Standardshttp://www.doeni.gov.uk/niea/european_a nd_national_drinking_water_quality_standards october 2011.pdf

[4] UNESCO (1996) Water Quality Assessments - A Guide to Use of Biota, Sediments and Water in Environmental Monitoring - Second Edition Edited by Deborah Chapman 
[5] Awopetu, M. S, Coker, A.O, Aribisala, J. O. \& Awopetu, S. O. (2013) Water Quality in Pipe Distribution Network: A Case Study of Eleyele Water Distribution Network in Ibadan, Nigeria. Wessex Institute of Technology Transaction, UK, pp $175-186$

[6] UNESCO, (2012) Groundwater Contamination Inventory: A Methodological Guide. http://www.unesdoc.unesco.org/images

[7] National Population Commission (NPC), (2006) Census Report, Federal Government of Nigeria Official Report Nigerian Industrial Standard http://www.unicef.org/nigeria/ng_publications_Nige rian_Standard_for_Drinking_Water_Quality.pdf

[8] Oriye Olusegun (2013). Urban expansion and urban land use in Ado Ekiti, Nigeria. American Journal of Research Communication, 1(2): 128-139\} www.usajournals.com ISSN: 2325-4076.

[9] Oyedele, E. A. A. and Olayinka, A. I. (2012) Statistical Evaluation of Groundwater Potential of Ado-Ekiti, South West, Nigeria. Transnational J. of Sci. \& Tech. Vol.2 No. 6, pp 110 - 127

[10] Awosusi, O. O. and Jegede A. O. (2013) Challenges of sustainability and urban Development: A Case study of Ado-Ekiti, Ekiti State, Nigeria. International Education Research, Vol. 1, Issue 1, 22-29.

[11] Adebayo, W. O. (1993), Weather and Climate. In F. S. Ebisemiju (Ed.). Ado-Ekiti region. A Geographical Analysis and Master Plan. Lagos Alpha Prints, pp11-14.

[12] American Public Health Association (APHA) (1994). Standard Methods for the Examination of Water and Wastewater. $15^{\text {th }}$ Edition. Washington DC USA

[13] WHO's drinking water standards . WHO's Guidelines for Drinking-water Quality, set up in Geneva.

http://www.lenntech.com/applications/drinking/ standards/who-s-drinking-water-standards.htm.

[14] European Union's drinking water standards. Council Directive 98/83/EC on the quality of water intended for human consumption. http://www.lenntech.com/applications/drinking/stan dards/eu-s-drinkingwater-standards.htm.

[15] Nigerian Standard for Drinking Water Quality http://www.unicef.org/nigeria/ng_publications_Nige rian_Standard_for_DrinkingWater_Quality.pdf 